Article

\title{
Highly Efficient Synthesis of Glutathione via a Genetic Engineering Enzymatic Method Coupled with Yeast ATP Generation
}

\author{
Chen Huang and Zhimin Yin * \\ Jiangsu Province Key Laboratory for Molecular and Medicine Biotechnology, College of Life Science, \\ Nanjing Normal University, Nanjing 210046, China; chen.huang95@foxmail.com \\ * Correspondence: yinzhimin@njnu.edu.cn
}

Received: 8 December 2019; Accepted: 23 December 2019; Published: 26 December 2019

\begin{abstract}
Glutathione is a tripeptide compound with many important physiological functions. A new, two-step reaction system has been developed to efficiently synthesize glutathione. In the first step, glutamate and cysteine are condensed to glutamyl-cysteine by endogenous yeast enzymes inside the yeast cell, while consuming ATP. In the second step, the yeast cell membrane is lysed by the permeabilizing agent CTAB (cetyltrimethylammonium bromide) to release the glutamyl-cysteine, upon which added glutathione synthetase converts the glutamyl-cysteine and added glycine into glutathione. The ATP needed for this conversion is supplied by the permeabilized yeast cells of glycolytic pathway. This method provided sufficient ATP, and reduced the feedback inhibition of glutathione for the first-step enzymatic reaction, thereby improving the catalytic efficiency of the enzyme reaction. In addition, the formation of suitable oxidative stress environment in the reaction system can further promote glutathione synthesis. By HPLC analysis of the glutathione, it was found that $2.1 \mathrm{~g} / \mathrm{L}$ reduced glutathione is produced and $17.5 \mathrm{~g} / \mathrm{L}$ oxidized glutathione. Therefore, the new reaction system not only increases the total glutathione, but also facilitates the subsequent separation and purification due to the larger proportion of oxidized glutathione in the reaction system.
\end{abstract}

Keywords: glutathione; glutathione synthetase; yeast energy coupling; post-addition CTAB method; oxidative stress environment

\section{Introduction}

Glutathione (GSH) is a bioactive tripeptide compound with $\gamma$-glutamyl and sulfhydryl groups consisting of L-glutamic acid, L-cysteine, and glycine [1]. It is ubiquitous in living organisms and plays a central role in cell biology. Glutathione is easily oxidized. Two molecules of reduced glutathione are oxidatively dehydrogenated and then disulfide bonded to form oxidized glutathione (GSSG), but only reduced glutathione has biological activity [2]. Oxidized glutathione can be reduced to active reduced glutathione with glutathione reductase by consuming NADPH (nicotinamide adenine dinucleotide phosphate) [3]. Glutathione maintains the intracellular redox balance through the transformation of oxidized and reduced states [4]. GSH can irreversibly bind to toxic electrophilic compounds that are to be eliminated outside the cell either spontaneously or via catalysis by glutathione s-transferase [5]. Related research shows that glutathione can be involved in DNA repair to protect against side effects caused by tumor drugs and other radiopharmaceuticals and radiotherapy [6,7]. In addition, glutathione has a skin-whitening effect in humans through the inhibition of melanogenesis by suppressing the activity of tyrosinase $[8,9]$. To summarize, important groups on the $\gamma$-peptide bond and the thiol group in the glutathione structure determine its various physiological functions, such as anti-oxidation [10], detoxification of exogenous substances [11], maintenance of the intracellular thiol balance [12], assisted 
amino acids transmembrane transport [13], DNA repair [6], anti-radiation [7], and other functions, so it is widely used in food, cosmetics, medicine, and other fields [8].

Glutathione has multiple metabolic pathways in cells. In all eukaryotic cells and most Gram-negative bacteria, glutamylcysteine synthetase (GSHI) first catalyzes the synthesis of glutamylcysteine from glutamate and cysteine by consuming ATP. Glutathione synthetase (GSHII) continues to catalyze the synthesis of glutathione from glutamylcysteine and glycine using ATP [14]. However, in Gram-negative bacteria, glutathione bifunctional synthase can directly catalyze three substrates to synthesize glutathione $[15,16]$. Additionally, there are some alternative pathways in prokaryotes $[17,18]$.

Over the years, researchers have explored a variety of methods for the efficient synthesis of glutathione based on these metabolic pathways. There are four main methods for producing glutathione: extraction, chemical synthesis, fermentation, and enzymatic methods. Extraction and chemical synthesis were the main early methods for the synthesis of glutathione, but they have been phased out due to low yields and other limitation. Fermentation is widely used in industry, but there are also problems such as the inhibition of intracellular products [19] and difficulty in separation and purification [20]. Enzymatic methods are currently the research focus. Enzymatic synthesis uses a two-step enzyme-catalyzed reaction system containing the glutathione synthetase system, three precursor amino acids, cofactors, and the necessary energy [21]. The advantages of the enzymatic production of GSH are mainly that the in vitro reaction system simplifies the production process and has strong specificity and mild reaction conditions, so that the yield of GSH can reach a high level. However, the transfer to the industrial scale has still not been achieved as efficient ATP supply and enzyme catalytic systems were lacking [22]. At present, the key to the enzymatic synthesis of GSH is to obtain a high-performance glutathione synthetase enzyme system and a high-efficiency ATP generation system.

Our work aims to further increase the yield of glutathione synthesis based on the enzymatic method and coupling with yeast energy production. The expression of GSH synthase can be improved by inserting the glutathione synthase gene into the prokaryotic expression system to construct the recombinant strain through genetic engineering [23]. Therefore, we first constructed pET28a-gshII recombinant plasmid and transformed it into E. coli BL21. Then, recombinant strains were induced to express large amounts of glutathione synthetase with different inducers. Additionally, this study has set up a new method called the "post-addition CTAB method" (cetyltrimethylammonium bromide, a permeabilizing agent), which not only effectively coupled the yeast energy production system but also greatly reduced the feedback inhibition of glutathione for the first step enzymatic reaction. Due to the characteristic of the glutathione redox state transition [4], the formation of a suitable oxidative stress environment in the reaction system can promote the synthesis of glutathione. This new reaction system can efficiently synthesize a large amount of GSSG and has obvious advantages in T-GSH synthesis.

\section{Results and Discussion}

\subsection{Induced Expression of Glutathione Synthetase}

High enzyme activity plays a decisive role in the enzymatic synthesis of glutathione [24]. In this new method, the activity of glutathione synthetase directly determines the efficiency of glutathione synthesis in the exogenous yeast enzyme reaction. Therefore, it is necessary to investigate the induction expression conditions of glutathione synthetase. The expression of glutathione synthetase was induced by Tianda No.1, IPTG (isopropyl-beta-D-thiogalactopyranoside) and lactose, and the effect of the induced expression is shown in Figure 1a. It was found that Tianda No. 1 has obvious advantages over IPTG and lactose as an inducer, and it can promote the expression of glutathione synthetase. When the cells are grown at a suitable temperature $\left(>30^{\circ} \mathrm{C}\right)$, they can be induced to express a large amount of proteins. However, the induced proteins are prone to be inclusion bodies or have misfolded spatial structure which affects the enzymatic activity [25]. Because enzymatic activity is a key factor in the 
reaction system, it is necessary to lower the induction temperature [26]. The expression of glutathione synthetase was induced at $30^{\circ} \mathrm{C}, 26^{\circ} \mathrm{C}, 22^{\circ} \mathrm{C}, 18^{\circ} \mathrm{C}, 14^{\circ} \mathrm{C}$, and $10^{\circ} \mathrm{C}$, and the effect of the induction temperature on glutathione synthetase is shown in Figure $1 \mathrm{~b}$. The recombinant protein has the highest expression at $26^{\circ} \mathrm{C}$, and $26^{\circ} \mathrm{C}$ was determined as the optimal induction temperature.

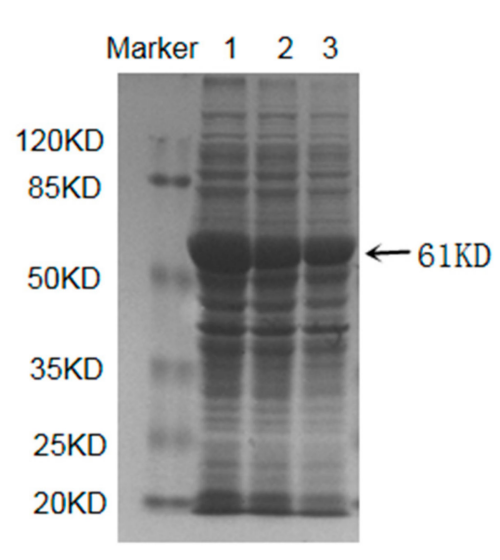

(a)

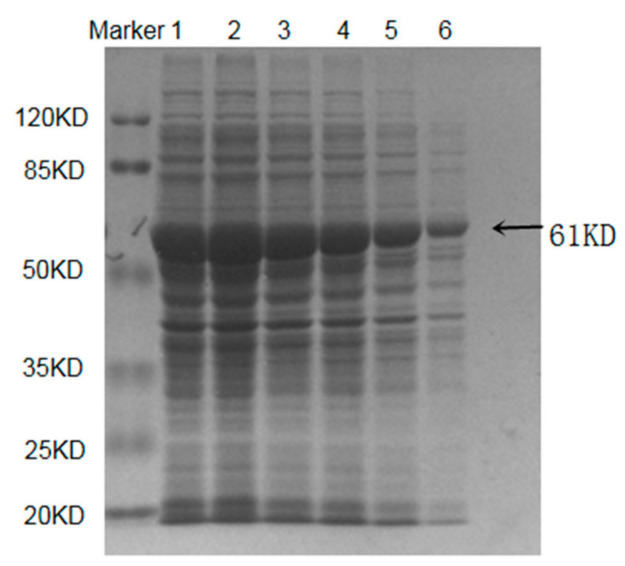

(b)

Figure 1. The induced expression of glutathione synthetase. (a) the effect of the different inducers. Lanes 1, 2, and 3 show GSH induced by Tianda No.1, lactose, and IPTG, respectively; (b) GSH at different low temperatures. Lanes 1-6 show the glutathione synthetase expression that was induced at $30{ }^{\circ} \mathrm{C}, 26^{\circ} \mathrm{C}, 22{ }^{\circ} \mathrm{C}, 18^{\circ} \mathrm{C}, 14^{\circ} \mathrm{C}$, and $10{ }^{\circ} \mathrm{C}$, respectively, by the Tianda No. 1.

\subsection{The Permeability of the Yeast Cells and Coupling with Yeast ATP Generation}

The synthesis of GSH by glutathione synthetase must be coupled with ATP produced by the yeast glycolytic pathway [27]. Therefore, the yeast cells need to be permeabilized to ensure the intracellular to extracellular diffusion of ATP. Shailasree Sekhar found that treatment with CTAB to alter the membrane permeability yielded higher catalase activity than digitonin and TritonX-100 [28]. CTAB is a cationic surfactant, and can lyse cell membranes by acting as membrane-modulating agent [29]. N-Lauroylsarcosine is a cationic detergent that is often used instead of SDS (sodium dodecyl sulfate) to solubilize proteins $[30,31]$. TritonX-100 is a mild non-ionic detergent used to solubilize cytoplasmic membrane proteins [31]. The cells were permeabilized with Tween-80, 1\% TritonX-100, $\mathrm{CTAB}, \mathrm{N}$-Lauroylsarcosine, and 30\% ethanol, respectively. The effect of the type of permeabilizing agent on GSH synthesis is shown in Figure 2a. As seen from the figure, CTAB and N-Lauroylsarcosine have the best effect; comparatively, the effect of $1 \%$ TritonX-100 is significantly lower, and $30 \%$ ethanol and Tween- 80 have no effect. Therefore, CTAB was chosen as a permeabilizing agent for the yeast cells. In this study, the yeast cells were able to produce approximately $21.61 \mathrm{mmol} / \mathrm{L} \mathrm{GSH}$ after CTAB permeation. Compared with other permeabilizing agents, CTAB can reduce the permeability barrier of the cell membrane to the greatest extent and therefore greatly increase the release of intracellular metabolites. 


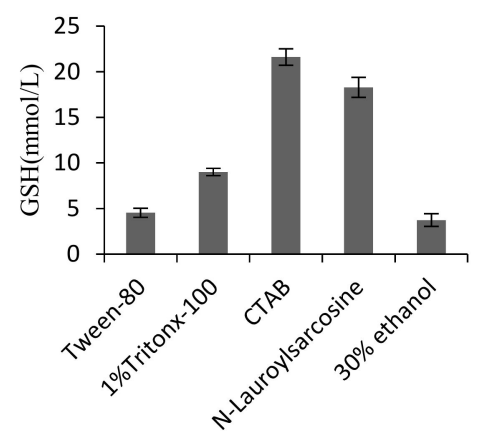

(a)

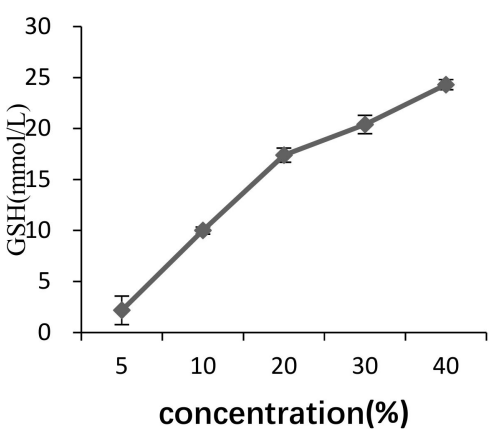

(b)

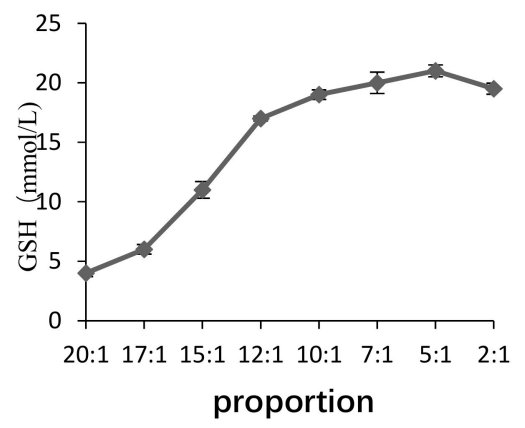

(c)

Figure 2. The effect of the permeability of yeast cells on GSH synthesis; (a) the effect of the different types of permeabilizing agents. The permeabilizing agents were Tween-80, $1 \%$ TritonX-100, CTAB, $\mathrm{N}$-Lauroylsarcosine, and 30\% ethanol; (b) the effect of the volume concentration of yeast cells. The yields are shown for the $100 \mathrm{~mL}$ reaction system with yeast cell volumes of $5 \%, 10 \%, 20 \%, 30 \%$, and $40 \%$; (c) the effect of the proportion of yeast to permeabilizing agent. The proportion of yeast to permeabilizing agent in the reaction system were 20:1, 15:1, 10:1, 5:1, and 2:1.

After selecting CTAB as the permeabilizing agent for the yeast cell membranes, it was necessary to investigate the volume concentration of yeast in the reaction medium. Yeast cells are so crucial for the first endogenous enzyme reaction that the yeast volume concentration directly affects the production of the final product. Different volume concentrations of yeast were added to the reaction system, and the substrate was reacted with the endogenous yeast enzyme for sufficient time (approximately $10 \mathrm{~h}$ ). Then, $\mathrm{CTAB}$ was added for permeabilization and the exogenous enzyme was simultaneously used to catalyze the reaction. The final concentration of GSH is shown in Figure 2b. It can be seen from the figure that the larger the volume concentration of yeast cells, the higher the concentration of synthesized GSH. However, the growth rate of GSH synthesis tends to slow down after the volume concentration of yeast cells exceeds $20 \%$. Moreover, if the concentration of yeast in the reaction system is too high, a large amount of bubbles will be generated in the reaction solution due to cellular respiration, which is not conducive to the continuous reaction. Considering the cost and the difficulty of separation and purification, a $20 \%$ yeast volume concentration of yeast is optimal.

The proportion of yeast to permeabilizing agent in the reaction system was 20:1, 15:1, 10:1, 5:1, or 2:1. The effect of the proportion of yeast to permeabilizing agent on the GSH synthesis is shown in Figure 2c. It can be seen from the figure that the smaller the proportion of yeast to permeabilizing agent, the higher the concentration of synthetic GSH, but the effect of the ratio of yeast to the permeabilizing agent is not significant in the range of 10:1 to 2:1. Since CTAB is a cationic detergent with certain cytotoxicity, if the concentration of the permeabilizing agent is too high, it can cause excessive damage of yeast cells. In particular, the activity of the glycolytic yeast enzymes will decrease and lead 
to a reduction in ATP generation from yeast glycolysis. Hence, 10:1 is the optimum ratio for the permeabilizing agent.

\subsection{Effective Energy Supply Is Necessary in the Post-Addition CTAB Method Reaction System}

The post-addition CTAB method is a new synthetic system based on the enzymatic synthesis of GSH. In the enzymatic method, the yeast cells are first permeated to release a large amount of ATP produced by intracellular glycolytic pathway, and then glutathione synthetase in the reaction system consumes ATP to synthesize glutathione [32]. However, the release of a large amount of ATP cannot be fully utilized by the glutathione synthetase system in the initial reaction stage, which will lead to the unnecessary loss of ATP. Additionally, the low activity of yeast due to the long coupling time leads to an insufficient energy supply for the subsequent reactions [33]. To solve these problems, in this study, the glutathione was first directly catalyzed by endogenous enzymes in the yeast cells, and CTAB was then added to permeate the cell membrane. At the same time, exogenous enzymes were added to continue to catalyze the synthesis of glutathione. This method shortens the coupling time and maintains the high glycolytic enzyme activity to provide sufficient ATP for the reaction. As a result, the efficiency of synthesizing GSH was greatly improved.

This method also reduces feedback suppression to some extent. Research shows that, when the accumulation of GSH in the organism reaches a certain concentration, GSH will be combined with the regulatory site of $\gamma$-glutamylcysteine synthetase which makes its binding site change to inactivate, and the synthesis of GSH will thus be inhibited by feedback [34]. In this new method, CTAB was added to the reaction system after the first-step endogenous yeast enzyme reaction was completed, which avoided the accumulation of the intermediate product GGC and the final product GSH in the cell, and released the ATP for the exogenous enzyme reaction. Glycolytic enzymes can effectively maintain the enzymatic activity to complete the second-step exogenous enzyme reaction.

The synthesis of glutathione requires two steps, each of which consumes one molecule of ATP [32]. It is necessary for us to consider how to provide an efficient and low-cost energy supply for the new method to take full advantage of its superiority. Six carbon sources of glucose, lactose, maltose, sucrose, FDP (Fructose-1, 6-diphosphate) and ATP, were added to the reaction system. The effect of the different carbon sources on glutathione synthesis is shown in Figure 3a. Among the six carbon sources, ATP can be used as a direct energy source to synthesize the most amount of GSH, reaching $27.81 \mathrm{mmol} / \mathrm{L}$. The GSH produced from glucose, lactose, maltose, sucrose, and FDP was $19.67 \mathrm{mmol} / \mathrm{L}, 13.59 \mathrm{mmol} / \mathrm{L}$, $16.69 \mathrm{mmol} / \mathrm{L}, 17.26 \mathrm{mmol} / \mathrm{L}$, and $17.60 \mathrm{mmol} / \mathrm{L}$, respectively. The other carbon sources need to be converted into ATP through the yeast cell glycolytic pathway [35], so the efficiency of synthesizing GSH from these carbon sources is not as high as the direct synthesis of GSH from ATP. However, ATP is so expensive that it is economically unfeasible to add ATP directly at an industrial scale. Therefore, glucose is the best carbon source for GSH synthesis. 


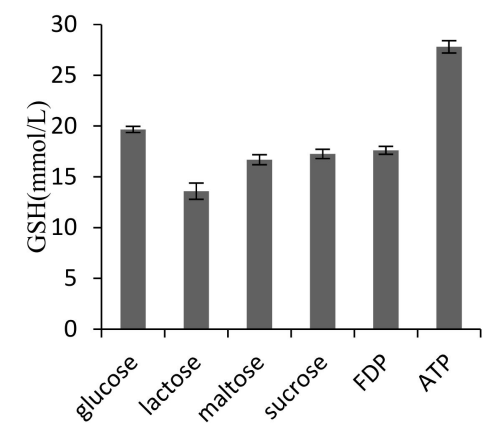

(a)

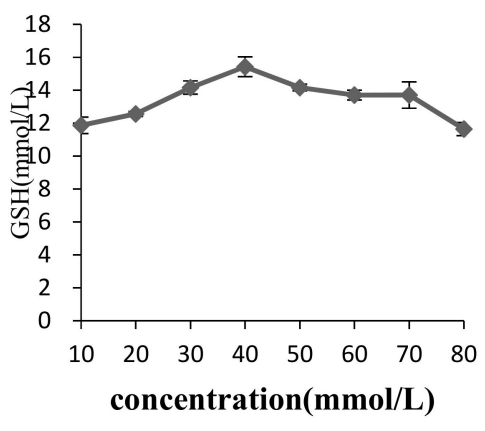

(c)

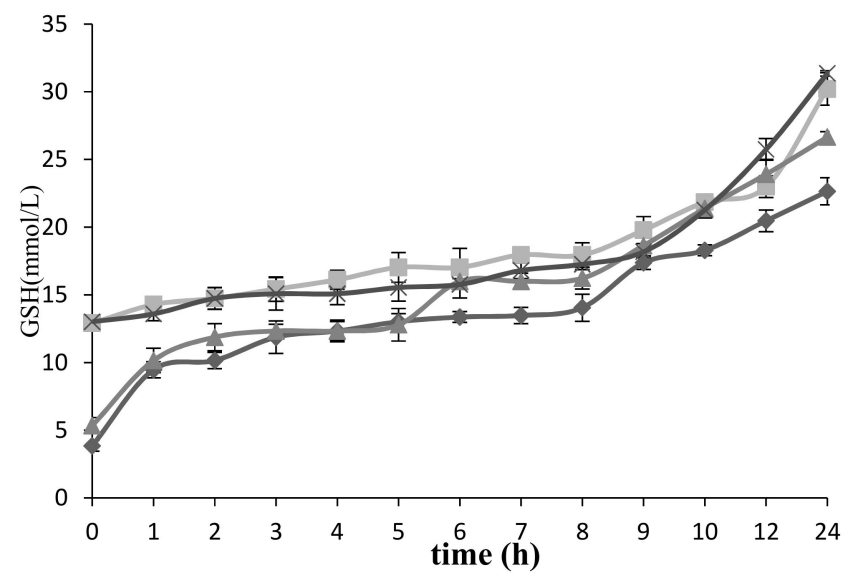

(e)

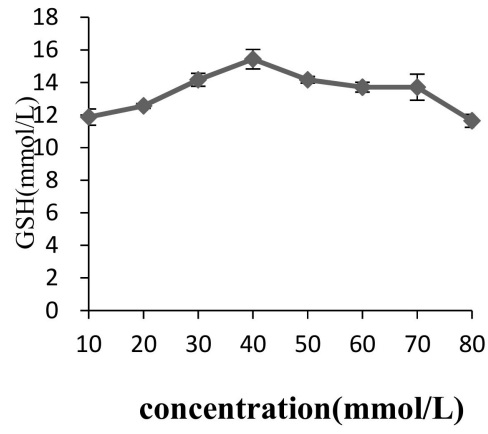

(b)

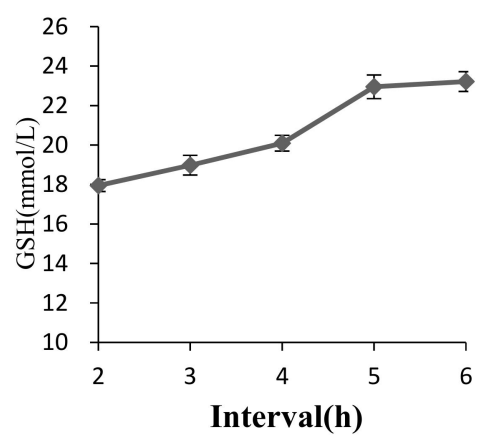

(d)

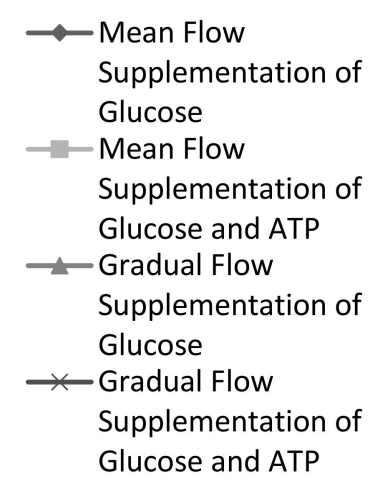

Glucose and ATP

Figure 3. The effect of the energy supply on the synthesis of glutathione in the reaction system with post-addition CTAB method. (a) the effect of different carbon sources. The six carbon sources were glucose, lactose, maltose, sucrose, FDP and ATP. (b) the effect of the initial glucose concentration, $10-80 \mathrm{mmol} / \mathrm{L}$; (c) the effect of the supplemental glucose concentration, $20-80 \mathrm{mmol} / \mathrm{L}$; (d) the effect of different supplementation times. After adding the permeabilizing agent, the interval before the supplemental glucose was added was $2 \mathrm{~h}, 3 \mathrm{~h}, 4 \mathrm{~h}, 5 \mathrm{~h}$, or $6 \mathrm{~h}$. (e) the effect of different ways of replenishment. The four ways of replenishing energy were mean flow supplementation of glucose, mean flow supplementation of glucose and ATP, gradual flow supplementation of glucose, and gradual flow supplementation of glucose and ATP.

The initial concentration, supplemental concentration, supplementation time, and the supplementation strategy of glucose are all critical to the reaction system of GSH synthesis. To the initial reaction system, 10-80 mmol/L of glucose were added, which was then mainly catalyzed by 
the yeast endogenous enzyme. The effect of the initial glucose concentration on the GSH synthesis is shown in Figure 3b. The endogenous yeast enzyme catalyzes the first step reaction for about $10 \mathrm{~h}$. Sufficient glutamyl-cysteine and ATP can be produced, which is most beneficial for the second step of the synthesis of glutathion catalyzed by the exogenous enzymes, as shown in Figure S1. After $10 \mathrm{~h}$ of reaction, CTAB was added to permeate the yeast cells. Next, $20-80 \mathrm{mmol} / \mathrm{L}$ of supplemental glucose was added for the reaction to continue to produce ATP. The effect of the supplemental glucose concentration on GSH synthesis is shown in Figure 3c. Glucose was added at $2 \mathrm{~h}, 3 \mathrm{~h}, 4 \mathrm{~h}, 5 \mathrm{~h}$, and $6 \mathrm{~h}$ after permeabilization. The effect of the glucose supplementation time on GSH synthesis is shown in Figure 3d. Four strategies for replenishing energy were used, namely, mean flow supplementation of glucose, mean flow supplementation of glucose and ATP, gradual flow supplementation of glucose, and gradual flow supplementation of glucose and ATP. The effect of the different strategies of energy replenishment on the GSH synthesis is shown in Figure 3e. As seen from Figure 3a-e, the optimal concentration for the initial addition of glucose is $40 \mathrm{mmol} / \mathrm{L}$. After using CTAB to permeate yeast cells, $30 \mathrm{mmol} / \mathrm{L}$ of glucose is added to synthesize more GSH at intervals of $5 \mathrm{~h}$ or $6 \mathrm{~h}$. Before adding CTAB, the yeast cells mainly undergo the tricarboxylic acid cycle in the mitochondria to produce a large amount of ATP to synthesize GSH. Therefore, in the early stage of the reaction, the yeast cells consume less glucose, so a shorter glucose supplementation interval will lead to glucose accumulation, which will inhibit the synthesis of GSH [36]. The glucose can be fully consumed in $5 \mathrm{~h}$ or $6 \mathrm{~h}$, and the energy can be replenished in time to promote GSH synthesis. Gradual flow supplementation is obviously superior to mean flow supplementation because it can better maintain the supply of energy and avoid excessive ATP in the system that would inhibit the synthesis of GSH. The combination with ATP is also superior to a single supplementation of glucose. Therefore, the gradual flow supplementation of glucose combined with ATP in the reaction system is more conducive to GSH synthesis.

\subsection{Oxidative Stress Environments Can Promote the Synthesis of GSH}

Many studies have shown that GSH-dependent reduction systems play an important role in resisting oxygen stresses for E. coli and Saccharomyces cerevisiae [37]. The active sulfhydryl group of GSH is oxidized by ROS to form oxidized glutathione, which can then be reduced to GSH under the action of glutathione reductase, thus removing the ROS and protecting the cell [38]. Under the induction of low concentrations of $\mathrm{H}_{2} \mathrm{O}_{2}$, it has been demonstrated that the proteins responsible for transcription regulation in yeast induce the transcription of genes in the GSH synthase line, thus producing more GSH to resist oxidative stresses [39]. The specificity of the glutathione redox transformation provides us with a new idea to improve the yield of GSH. Yeast cells were treated with different conditions of oxidative stress to observe if glutathione synthesis was promoted. Different concentrations of $\mathrm{Mn}^{2+} / \mathrm{H}_{2} \mathrm{O}_{2} / \mathrm{Fe}^{3+}\left(\mathrm{MnCl}_{2} / \mathrm{H}_{2} \mathrm{O}_{2} / \mathrm{FeCl}_{3} \cdot 6 \mathrm{H}_{2} \mathrm{O}\right)$ were added as stress agents to the reaction system to form an oxidative stress environment. A control group was assigned for each experiment. As seen from Figure $4 \mathrm{a}-\mathrm{e}$, compared with the control group, the oxidative conditions at different low concentrations all promoted the synthesis of glutathione. In addition, when each stressor was added alone, we found that the optimal concentrations were $20 \mathrm{mmol} / \mathrm{L}$ for $\mathrm{Mn}^{2+}, 20 \mu \mathrm{L} / 100 \mathrm{~mL}$ for $\mathrm{H}_{2} \mathrm{O}_{2}$, and $2.22 \mathrm{mmol} / \mathrm{L}$ for $\mathrm{Fe}^{3+}$. When $20 \mathrm{mmol} / \mathrm{L} \mathrm{Mn}^{2+}$ was combined with different concentrations of $\mathrm{H}_{2} \mathrm{O}_{2}$ and $\mathrm{Fe}^{3+}$, the optimal concentrations were $20 \mathrm{mmol} / \mathrm{L}$ of $\mathrm{Mn}^{2+}, 10 \mu \mathrm{L} / 100 \mathrm{~mL}$ of $\mathrm{H}_{2} \mathrm{O}_{2}$, and $1.48 \mathrm{mmol} / \mathrm{L}$ of $\mathrm{Fe}^{3+}$. Glutathione can alternate between its oxidized and reduced states, so it can effectively maintain the intracellular redox balance [4]. When stimulated by oxidative stresses, yeast cells will synthesize more GSH to protect themselves and resist the adverse environments [40]. Stress agents may also affect the structure of glutathione synthetase [41]. When the enzyme structure changes, the enzymatic activity of glutathione synthetase is fully stimulated to catalyze GSH synthesis. 


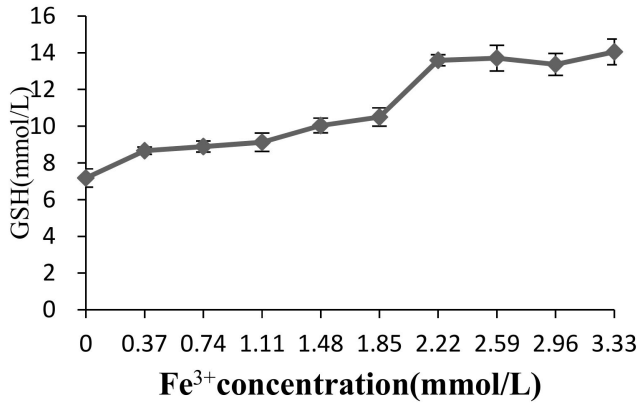

(a)

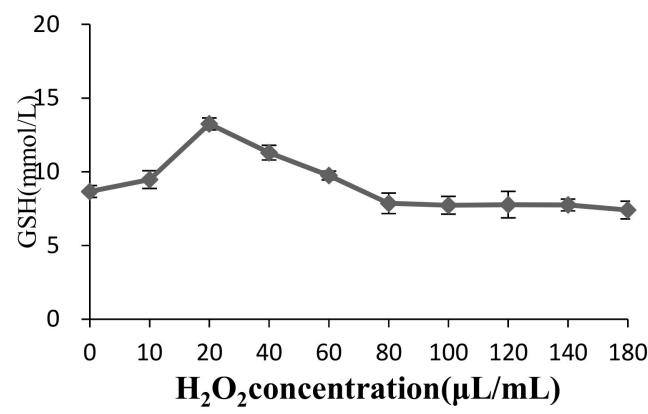

(c)

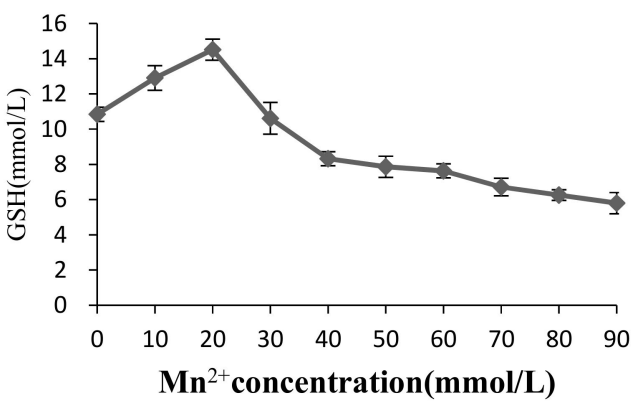

(b)

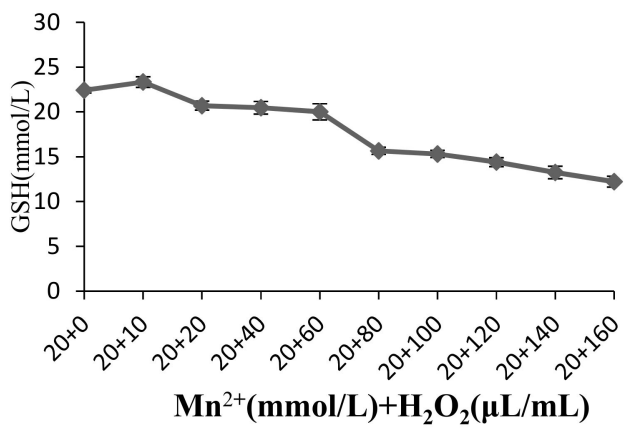

(d)

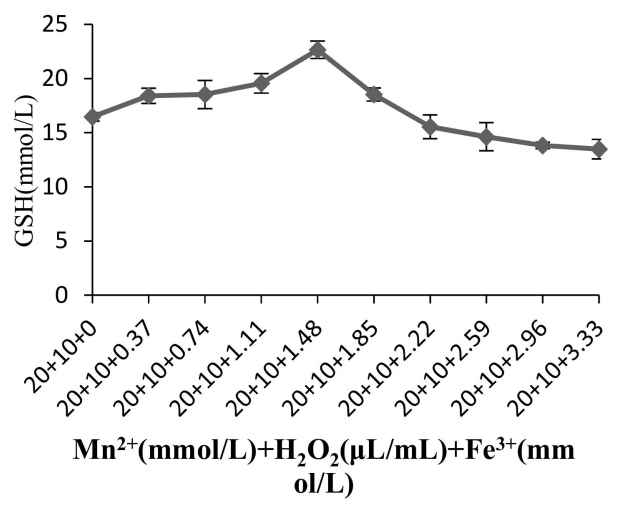

(e)

Figure 4. The effect of oxidative stress environment on glutathione synthesis (in the $100 \mathrm{~mL}$ reaction system). (a) the effect of different $\mathrm{Mn}^{2+}$ concentrations, $0 \mathrm{mmol} / \mathrm{L}$ (control) $-90 \mathrm{mmol} / \mathrm{L}$; (b) the effect of different $\mathrm{H}_{2} \mathrm{O}_{2}$ concentrations, $0 \mu \mathrm{L} / \mathrm{mL}$ (control)-180 $\mu \mathrm{L} / \mathrm{mL}$; (c) the effect of different $\mathrm{Fe}^{3+}$ concentrations, $0 \mathrm{mmol} / \mathrm{L}$ (control) $-3.33 \mathrm{mmol} / \mathrm{L}$; (d) the effect of $\mathrm{Mn}^{2+}(20 \mathrm{mmol} / \mathrm{L}$ ) combined with $\mathrm{H}_{2} \mathrm{O}_{2}$ at different concentrations, $0 \mu \mathrm{L} / \mathrm{mL}$ (control) $-160 \mu \mathrm{L} / \mathrm{mL}$; (e) the effect of $\mathrm{Mn}^{2+}(20 \mathrm{mmol} / \mathrm{L}$ ) and $\mathrm{H}_{2} \mathrm{O}_{2}(10 \mu \mathrm{L} / \mathrm{mL})$ combined with $\mathrm{Fe}^{3+}$ at different concentrations, $0 \mathrm{mmol} / \mathrm{L}$ (control)-3.33 mmol/L.

In this new post-addition $\mathrm{CTAB}$ method reaction system, three types of stress agents are combined to form oxidative stress environments, and various regulatory factors are added according to the optimized results. Reduced glutathione and oxidized glutathione were detected by HPLC as shown in Figure 5. The final concentration of GSH can reach $2.1 \mathrm{~g} / \mathrm{L}$, and the final concentration of GSSG can reach $17.5 \mathrm{~g} / \mathrm{L}$ in the reaction system. GSSG has a larger proportion than GSH in the final product, and GSSG is easier to separate than GSH, which is conducive to downstream processing. In the subsequent separation and purification, the oxidized glutathione can be removed by using a reducing agent [42]. 


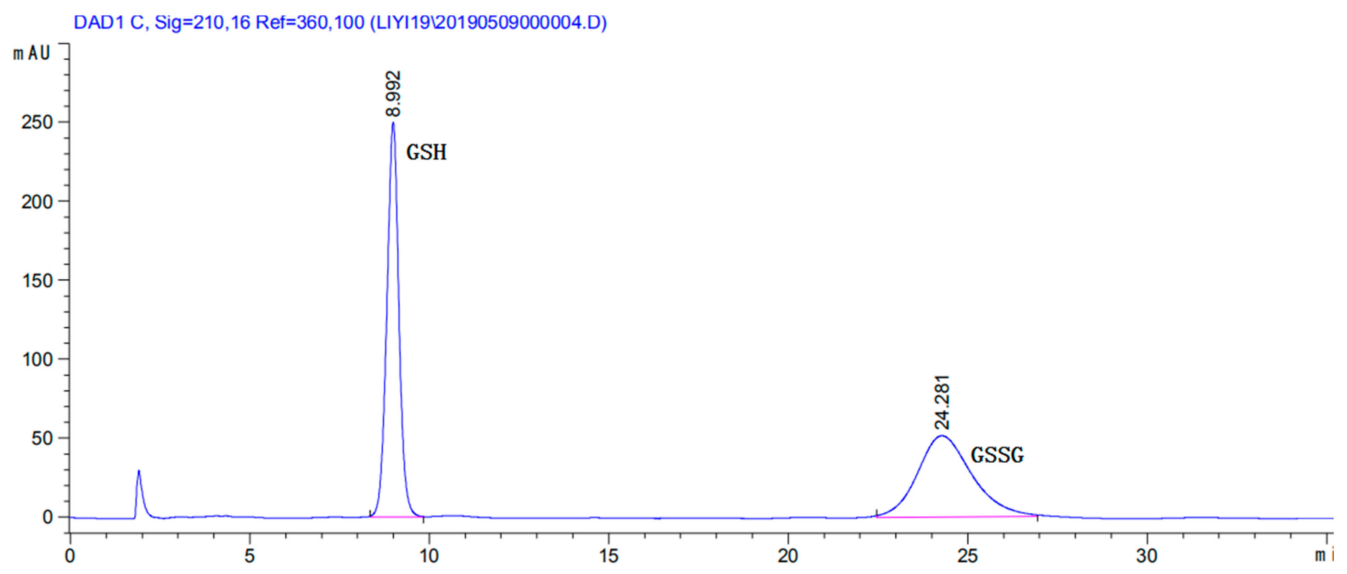

(a)

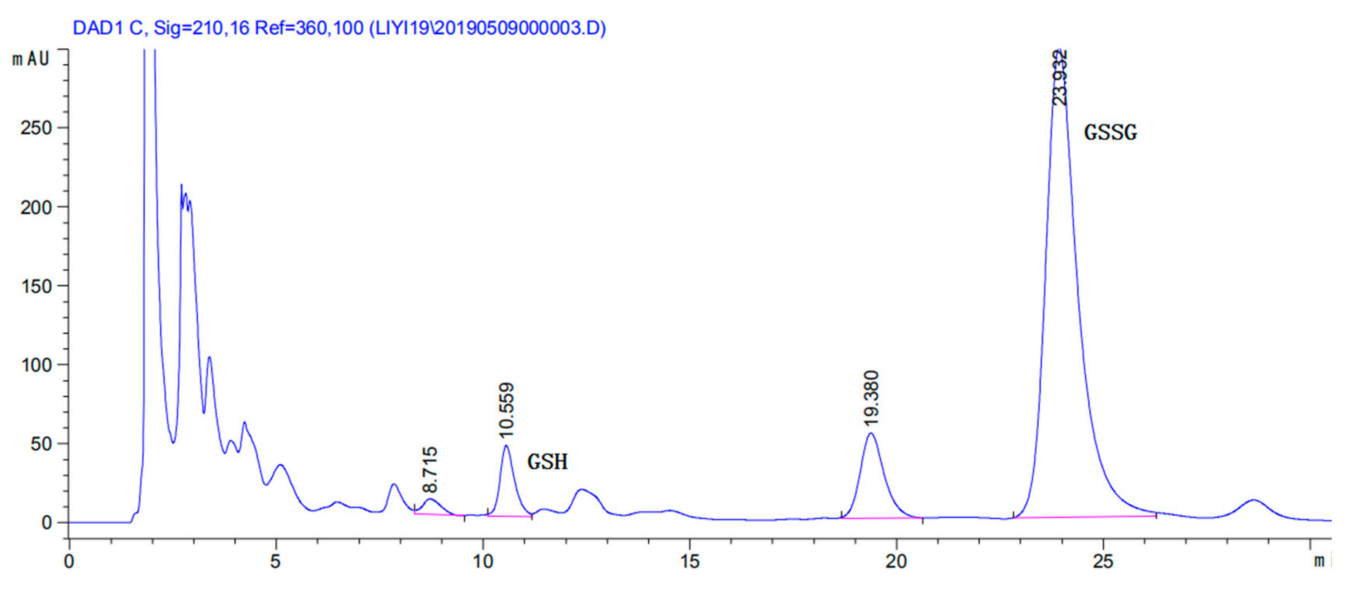

(b)

Figure 5. Glutathione analysis by HPLC. (a) analysis of GSH and GSSG standards by HPLC; (b) analysis of GSH and GSSG samples by HPLC.

\section{Materials and Methods}

\subsection{Plasmids, Strains, and Reagents}

Saccharomyces cerevisiae SP5 is the main experimental yeast strain preserved by Jiangsu Province Key Laboratory for Molecular and Medicine Biotechnology. E. coli DH5 $\alpha$, E. coli BL21 (DE3), expression vector PET-28a (+) and Saccharomyces cerevisiae were stored in the laboratory at $-80{ }^{\circ} \mathrm{C}$. Taq DNA polymerase, T4 DNA ligase, restriction endonuclease, and DNA molecular weight markers were purchased from TaKaRa (Dalian, China); protein molecular weight markers were purchased from MBI; primer synthesis and plasmid sequencing were performed by General Biosystems (Anhui, China); Tianda No.1, a rapid and efficient protein expression inducer, was developed in our laboratory and commercialized by Nanjing Bioworld Company (Nanjing, China).

\subsection{Construction of the pET28a-gshII Recombinant Plasmid}

Primers were designed based on the gshII gene sequence of Saccharomyces cerevisiae and the MCS site of pET28a, and the NcoI and BamH I restriction sites were inserted at the $5^{\prime}$ end of the upstream and downstream primers, respectively, F: 5'-CATGCCATGGATGGCACACTATCCACCT-3', R: 5'-CGCGGATCCCTAGTAAAGAATAATACT-3'. The primers were sent to General Biosystems for synthesis. The whole genome sequence of Saccharomyces cerevisiae was extracted as a template amplified by PCR: $5 \mathrm{~min}$ at $95^{\circ} \mathrm{C} ; 25 \times\left(40 \mathrm{~s}\right.$ at $95^{\circ} \mathrm{C}, 18 \mathrm{~s}$ at $53^{\circ} \mathrm{C}, 1 \mathrm{~min} 30 \mathrm{~s}$ at $\left.72{ }^{\circ} \mathrm{C}\right)$; stored at $4{ }^{\circ} \mathrm{C}$. 
The target gene obtained by PCR and the pET-28a (+) vector were digested with NcoI and BamHI, respectively, and then ligated into $E$. coli DH $5 \alpha$ competent cells by T4 DNA ligase, and plated overnight at $37^{\circ} \mathrm{C}$ to screen for positive clones. Finally, the DNA sequence was found to be identical to the template sequence. This recombinant plasmid was designated as pET28a-gshII. The molecular weight of glutathione synthetase is approximately $61 \mathrm{KD}$.

\subsection{The Reaction System of Glutathione Synthetase Coupled with Yeast Energy Production}

Endogenous yeast enzyme reaction: in the $100 \mathrm{~mL}$ reaction system, the yeast volume ratio was approximately $20 \%$. Three precursor amino acids (Glu/Gly/Cys) were added to the reaction system at

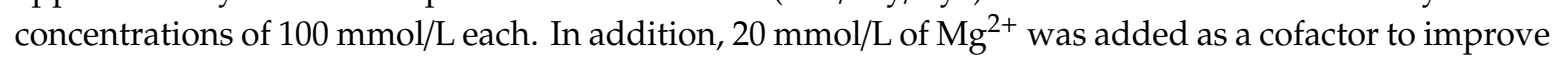
the activity of a yeast glycolysis enzyme system [43], and $40 \mathrm{mmol} / \mathrm{L}$ phosphate buffer was added $\left(\mathrm{K}_{2} \mathrm{HPO}_{4} \cdot 3 \mathrm{H}_{2} \mathrm{O}, \mathrm{NaH}_{2} \mathrm{PO}_{4} \cdot 2 \mathrm{H}_{2} \mathrm{O}\right)$. In this stage, the reaction $\mathrm{pH}$ should be kept at approximately 6.5 . Different kinds of carbon source medium (glucose, lactose, maltose, sucrose, FDP, and ATP) were used to provide energy for the endogenous enzyme reaction. The endogenous yeast enzyme reaction was performed under aerobic conditions at $37^{\circ} \mathrm{C}$ with shaking at $220 \mathrm{rpm}$ for $10 \mathrm{~h}$.

Exogenous yeast enzyme reaction: After $10 \mathrm{~h}$ for the endogenous yeast enzyme reaction, CTAB was added at a ratio of yeast to the permeabilizing agent of 10:1 to lyse the yeast cell membrane to release the intermediate products and ATP. Phosphate buffer $\left(\mathrm{K}_{2} \mathrm{HPO}_{4} \cdot 3 \mathrm{H}_{2} \mathrm{O}, \mathrm{NaH}_{2} \mathrm{PO}_{4} \cdot 2 \mathrm{H}_{2} \mathrm{O}\right)$ was added at $25 \mathrm{mmol} / \mathrm{L}$, and the reaction $\mathrm{pH}$ was adjusted to 5.5 . Then, $24 \mathrm{mg} / \mathrm{mL}$ of the exogenous enzyme was added to continue to catalyze the synthesis of glutathione. At the same time, $20 \mathrm{mmol} / \mathrm{L}$ of Glu, $10 \mathrm{mmol} / \mathrm{L}$ of Cys, $30 \mathrm{mmol} / \mathrm{L}$ of Gly, and $1 \mathrm{~g}$ of ATP were also added. At intervals of $5 \mathrm{~h}$ or $6 \mathrm{~h}$, $30 \mathrm{mmol} / \mathrm{L}$ of supplemental glucose was added. In this stage, the glucose provides sufficient energy for yeast exogenous enzyme reaction through the glycolytic pathway.

Permeabilizing yeast cells and coupling with yeast energy: in the reaction system, yeast and the permeabilizing agent CTAB were added in the proportion of 10:1 for permeabilization. Before permeabilization, the yeast cells mainly undergo the mitochondrial tricarboxylic acid cycle to produce ATP for the first-step enzymatic reaction [33], and after permeabilization, the yeast cells mainly perform glycolysis to produce ATP for the second-step enzymatic reaction due to the damage of the cell membrane [32]. The yeast cells transform the carbon source to ATP, which provides sufficient energy for the glutathione synthetase catalytic reaction.

\subsection{Glutathione Analysis}

Glutathione was analyzed using an Agilent 1200 high-performance liquid chromatograph. The column was Intersil ODS-3 C18, $250 \mathrm{~mm} \times 4.6 \mathrm{~mm}, 5 \mu \mathrm{m}$. The mobile phase had a ratio of A:B of 90:10 (v:v). Phase A was a sodium heptanesulfonate-phosphate buffer solution, where $3.4 \mathrm{~g}$ potassium dihydrogen phosphate and $1.1 \mathrm{~g}$ sodium heptane sulfonate were dissolved in $500 \mathrm{~mL}$ water. The $\mathrm{pH}$ of the solution was adjusted to 3.0 with phosphoric acid. Phase B was methanol. A $0.45 \mu \mathrm{m}$ microporous membrane was used to filter the phase $\mathrm{A}$ and phase $\mathrm{B}$. The detection wavelength was $210 \mathrm{~nm}$, the flow rate was $1.0 \mathrm{~mL} / \mathrm{min}$, and the injection volume was $20 \mu \mathrm{L}[44,45]$.

Standard solutions of glutathione were prepared at concentrations of $5 \mu \mathrm{g} / \mathrm{mL}, 10 \mu \mathrm{g} / \mathrm{mL}$, $20 \mu \mathrm{g} / \mathrm{mL}, 40 \mu \mathrm{g} / \mathrm{mL}$, and $60 \mu \mathrm{g} / \mathrm{mL}$ to draw a glutathione standard curve, and then samples were injected for analysis.

\section{Conclusions}

The glutathione was synthesized based on the enzymatic method, and the reaction system has been improved. First, a large amount of glutamylcysteine and a small amount of glutathione were synthesized by endogenous enzymes. Then, CTAB was used to permeate the yeast cells, and the exogenous enzyme was added to continue catalyzing GCC to synthesize GSH. This method not only effectively couples yeast ATP generation, but also reduces the feedback inhibition. The energy supply of the reaction system is optimized. A moderate oxidative stress environment can promote the synthesis 
of glutathione. The post-addition CTAB method has obvious advantages in promoting the synthesis of T-GSH.

Supplementary Materials: The following are available online at http://www.mdpi.com/2073-4344/10/1/33/s1, Figure S1: The effect of the first-step reaction time on glutathione synthesis.

Author Contributions: Project administration, Z.Y.; Writing—original draft, C.H. All authors have read and agreed to the published version of the manuscript.

Funding: This research is funded by the Priority Academic Program Development of Jiangsu Higher Education Institutions (PADD).

Acknowledgments: This study was supported by Nanjing 1718 Biotechnology Company Ltd.

Conflicts of Interest: The authors declare that they have no competing interests.

\section{References}

1. Meister, A.; Anderson, M.E. Glutathione. Annu. Rev. Biochem. 1983, 52, 711-760. [CrossRef]

2. Kaplowitz, N.; Aw, T.Y.; Ookhtens, M. The regulation of hepatic glutathione. Annu. Rev. Pharmacol. Toxicol. 1985, 25, 715-744. [CrossRef]

3. Carmel-Harel, O.; Storz, G. Roles of the glutathione-And thioredoxin-dependent reduction systems in the Escherichia coli and saccharomyces cerevisiae responses to oxidative stress. Annu. Rev. Microbiol. 2000, 54, 439-461. [CrossRef]

4. Diaz-Vivancos, P.; de Simone, A.; Kiddle, G.; Foyer, C.H. Glutathione-Linking cell proliferation to oxidative stress. Free Radic. Biol. Med. 2015, 89, 1154-1164. [CrossRef]

5. Behrens, K.A.; Jania, L.A.; Snouwaert, J.N.; Nguyen, M.; Moy, S.S.; Tikunov, A.P.; Macdonald, J.M.; Koller, B.H. Beyond detoxification: Pleiotropic functions of multiple glutathione S-transferase isoforms protect mice against a toxic electrophile. PLoS ONE 2019, 14, e0225449. [CrossRef]

6. Dannenmann, B.; Lehle, S.; Hildebrand, D.G.; Kubler, A.; Grondona, P.; Schmid, V.; Holzer, K.; Froschl, M.; Essmann, F.; Rothfuss, O.; et al. High glutathione and glutathione peroxidase-2 levels mediate cell-type-specific DNA damage protection in human induced pluripotent stem cells. Stem Cell Rep. 2015, 4, 886-898. [CrossRef]

7. Sappington, D.R.; Siegel, E.R.; Hiatt, G.; Desai, A.; Penney, R.B.; Jamshidi-Parsian, A.; Griffin, R.J.; Boysen, G. Glutamine drives glutathione synthesis and contributes to radiation sensitivity of A549 and H460 lung cancer cell lines. Biochim. Biophys. Acta (BBA)-Gen. Subj. 2016, 1860, 836-843. [CrossRef]

8. Weschawalit, S.; Thongthip, S.; Phutrakool, P.; Asawanonda, P. Glutathione and its antiaging and antimelanogenic effects. Clin. Cosmet. Investig. Dermatol. 2017, 10, 147-153. [CrossRef]

9. Watanabe, F.; Hashizume, E.; Chan, G.P.; Kamimura, A. Skin-whitening and skin-condition-improving effects of topical oxidized glutathione: A double-blind and placebo-controlled clinical trial in healthy women. Clin. Cosmet. Investig. Dermatol. 2014, 7, 267-274. [CrossRef]

10. Will, Y. Overview of glutathione function and metabolism. Curr. Protoc. Toxicol. 2001. [CrossRef]

11. Wu, G.; Fang, Y.Z.; Yang, S.; Lupton, J.R.; Turner, N.D. Glutathione metabolism and its implications for health. J. Nutr. 2004, 134, 489-492. [CrossRef]

12. Ketterer, B.; Coles, B.; Meyer, D.J. The role of glutathione in detoxication. Environ. Health Perspect. 1983, 49, 59-69. [CrossRef]

13. Orlowski, M.; Meister, A. The gamma-glutamyl cycle: A possible transport system for amino acids. Proc. Natl. Acad. Sci. USA 1970, 67, 1248-1255. [CrossRef]

14. Li, Y.; Wei, G.; Chen, J. Glutathione: A review on biotechnological production. Appl. Microbiol. Biotechnol. 2004, 66, 233-242. [CrossRef]

15. Vergauwen, B.; de Vos, D.; Van Beeumen, J.J. Characterization of the bifunctional gamma-glutamate-cysteine ligase/glutathione synthetase (GshF) of Pasteurella multocida. J. Biol. Chem. 2006, 281, 4380-4394. [CrossRef]

16. Gopal, S.; Borovok, I.; Ofer, A.; Yanku, M.; Cohen, G.; Goebel, W.; Kreft, J.; Aharonowitz, Y. A multidomain fusion protein in Listeria monocytogenes catalyzes the two primary activities for glutathione biosynthesis. J. Bacteriol. 2005, 187, 3839-3847. [CrossRef]

17. Sakato, K.; Tanaka, H. Advanced control of glutathione fermentation process. Biotechnol. Bioeng. 1992, 40, 904-912. [CrossRef] 
18. Spector, D.; Labarre, J.; Toledano, M.B. A genetic investigation of the essential role of glutathione: Mutations in the proline biosynthesis pathway are the only suppressors of glutathione auxotrophy in yeast. J. Biol. Chem. 2001, 276, 7011-7016. [CrossRef]

19. Wei, G.; Li, Y.; Du, G.; Chen, J. Application of a two-stage temperature control strategy for enhanced glutathione production in the batch fermentation by Candida utilis. Biotechnol. Lett. 2003, 25, 887-890. [CrossRef]

20. Johnston, R.B.; Bloch, K. Enzymatic synthesis of glutathione. J. Biol. Chem. 1951, 188, 221-240.

21. Li, W.; Li, Z.; Ye, Q. Enzymatic synthesis of glutathione using yeast cells in two-stage reaction. Bioprocess Biosyst. Eng. 2010, 33, 675-682. [CrossRef]

22. Schmacht, M.; Lorenz, E.; Senz, M. Microbial production of glutathione. World J. Microbiol. Biotechnol. 2017, 33, 106. [CrossRef]

23. Liao, X.Y.; Shen, W.; Chen, J.; Li, Y.; Du, G.C. Improved glutathione production by gene expression in Escherichia coli. Lett. Appl. Microbiol. 2006, 43, 211-214. [CrossRef]

24. Forman, H.J.; Zhang, H.; Rinna, A. Glutathione: Overview of its protective roles, measurement, and biosynthesis. Mol. Asp. Med. 2009, 30,1-12. [CrossRef]

25. Markossian, K.A.; Kurganov, B.I. Protein folding, misfolding, and aggregation. Formation of inclusion bodies and aggresomes. Biochemistry (Moscow) 2004, 69, 971-984. [CrossRef]

26. Thuy Le, A.T.; Schumann, W. A novel cold-inducible expression system for Bacillus subtilis. Protein Expr. Purif. 2007, 53, 264-269. [CrossRef]

27. Murata, K.; Tani, K.; Kato, J.; Chibata, I. Continuous production of glutathione using immobilized microbial cells containing ATP generating system. Biochimie 1980, 62, 347-352. [CrossRef]

28. Sekhar, S.; Bhat, N.; Bhat, S.G. Preparation of detergent permeabilized Bakers' yeast whole cell catalase. Process. Biochem. 1999, 34, 349-354. [CrossRef]

29. Raicu, V.; Gusbeth, C.; Anghel, D.F.; Turcu, G. Effects of cetyltrimethylammonium bromide (CTAB) surfactant upon the dielectric properties of yeast cells. Biochim. Biophys. Acta 1998, 1379, 7-15. [CrossRef]

30. Abraham, J.; Bhat, S.G. Permeabilization of baker's yeast with N-lauroyl sarcosine. J. Ind. Microbiol. Biotechnol. 2008, 35, 799-804. [CrossRef]

31. Rollini, M.; Musatti, A.; Manzoni, M. Production of glutathione in extracellular form by Saccharomyces cerevisiae. Process. Biochem. 2010, 45, 441-445. [CrossRef]

32. Liao, X.; Deng, T.; Zhu, Y.; Du, G.; Chen, J. Enhancement of glutathione production by altering adenosine metabolism of Escherichia coli in a coupled ATP regeneration system with Saccharomyces cerevisiae. J. Appl. Microbiol. 2008, 104, 345-352. [CrossRef]

33. Hara, K.Y.; Shimodate, N.; Hirokawa, Y.; Ito, M.; Baba, T.; Mori, H.; Mori, H. Glutathione production by efficient ATP-regenerating Escherichia coli mutants. FEMS Microbiol. Lett. 2009, 297, 217-224. [CrossRef]

34. Richman, P.G.; Meister, A. Regulation of gamma-glutamyl-cysteine synthetase by nonallosteric feedback inhibition by glutathione. J. Biol. Chem. 1975, 250, 1422-1426.

35. Liu, J.; Li, H.; Xiong, H.; Xie, X.; Chen, N.; Zhao, G.; Caiyin, Q.; Zhu, H.; Qiao, J. Two-stage carbon distribution and cofactor generation for improving 1-threonine production of Escherichia coli. Biotechnol. Bioeng. 2019, 116, 110-120. [CrossRef]

36. Shang, F.; Wang, Z.; Tan, T. High-cell-density cultivation for co-production of ergosterol and reduced glutathione by Saccharomyces cerevisiae. Appl. Microbiol. Biotechnol. 2008, 77, 1233-1240. [CrossRef]

37. Rodrigues-Pousada, C.; Devaux, F.; Caetano, S.M.; Pimentel, C.; da Silva, S.; Cordeiro, A.C.; Amaral, C. Yeast AP-1 like transcription factors (Yap) and stress response: A current overview. Microb. Cell 2019, 6, 267. [CrossRef]

38. Jamieson, D.J. Oxidative stress responses of the yeast Saccharomyces cerevisiae. Yeast 1998, 14, 1511-1527. [CrossRef]

39. Stephen, D.W.; Rivers, S.L.; Jamieson, D.J. The role of the YAP1 and YAP2 genes in the regulation of the adaptive oxidative stress responses of Saccharomyces cerevisiae. Mol. Microbiol. 1995, 16, 415-423. [CrossRef]

40. Wang, T.; Lu, W.; Lu, S.; Kong, J. Protective role of glutathione against oxidative stress in Streptococcus thermophilus. Int. Dairy J. 2015, 45, 41-47. [CrossRef]

41. Deponte, M. Glutathione catalysis and the reaction mechanisms of glutathione-dependent enzymes. Biochim. Biophys. Acta 2013, 1830, 3217-3266. [CrossRef] 
42. Pastore, A.; Federici, G.; Bertini, E.; Piemonte, F. Analysis of glutathione: Implication in redox and detoxification. Clin. Chim. Acta 2003, 333, 19-39. [CrossRef]

43. Laughlin, M.R.; Thompson, D. The regulatory role for magnesium in glycolytic flux of the human erythrocyte. J. Biol. Chem. 1996, 271, 28977-28983. [CrossRef]

44. Paroni, R.; De Vecchi, E.; Cighetti, G.; Arcelloni, C.; Fermo, I.; Grossi, A.; Bonini, P. HPLC with o-phthalaldehyde precolumn derivatization to measure total, oxidized, and protein-bound glutathione in blood, plasma, and tissue. Clin. Chem. 1995, 41, 448-454.

45. Cereser, C.; Guichard, J.; Drai, J.; Bannier, E.; Garcia, I.; Boget, S.; Parvaz, P.; Revol, A. Quantitation of reduced and total glutathione at the femtomole level by high-performance liquid chromatography with fluorescence detection: Application to red blood cells and cultured fibroblasts. J. Chromatogr. B Biomed. Sci. Appl. 2001, 752, 123-132. [CrossRef]

(C) 2019 by the authors. Licensee MDPI, Basel, Switzerland. This article is an open access article distributed under the terms and conditions of the Creative Commons Attribution (CC BY) license (http://creativecommons.org/licenses/by/4.0/). 